\title{
Regulation of dorsal somitic cell fates: BMPs and Noggin control the timing and pattem of myogenic regulator expression
}

\author{
Ram Reshef, Miguel Maroto, and Andrew B. Lassar ${ }^{1}$ \\ Department of Biological Chemistry and Molecular Pharmacology, Harvard Medical School, \\ Boston, Massachusetts 02115 USA
}

\begin{abstract}
Previous work has indicated that signals from the neural tube, notochord, and surface ectoderm promote somitic myogenesis. Here, we show that somitic myogenesis is under negative regulation as well; BMP signaling serves to inhibit the activation of MyoD and Myf5 in Pax3-expressing cells. Furthermore, we show that the BMP antagonist Noggin is expressed within the dorsomedial lip of the dermomyotome, where Pax3-expressing cells first initiate the expression of MyoD and Myf5 to give rise to myotomal cells in the medial somite. Consistent with the expression of Noggin in dorsomedial dermomyotomal cells that lie adjacent to the dorsal neural tube, we have found that coculture of somites with fibroblasts programmed to secrete Wnt1, which is expressed in dorsal neural tube, can induce somitic Noggin expression. Ectopic expression of Noggin lateral to the somite dramatically expands MyoD expression into the lateral regions of the somite, represses Pax3 expression in this tissue, and induces formation of a lateral myotome. Together, our findings indicate that the timing and location of myogenesis within the somite is controlled by relative levels of BMP activity and localized expression of a BMP antagonist.
\end{abstract}

[Key Words: BM P; Myf5; Pax3; somitic myogenesis; Noggin]

Received September 15, 1997; revised version accepted N ovember 25, 1997.

Skel etal muscle in vertebrates arises from precursor cells in the somites, transient metameric structures within the paraxial mesoderm. The somite is initially a sphere of columnar epithelial cells. Subsequently, the ventral somite de-epithelializes to give rise to the sclerotome, a precursor tissue for the vertebral column. The remaining dorsal epithelium of the somite, the dermomyotome, gives rise to both skeletal muscle and dermis. Cells within the dermomyotome express Pax3, a paired and homeodomain-containing transcription factor. As these cells migrate medially through the dorsomedial lip of the dermomyotome to form an epithelial sheet, the myotome (Denetclaw et al. 1997), they initiate the expression of MyoD and Myf5 (Ott et al. 1991; Barth and Ivarie 1994; Pownall 1992) and simultaneousl y lose the expression of Pax3 (Goulding et al. 1994; Williams and Ordahl 1994; M arcelle et al . 1995). M yogenesis is first observed in the myotome, which derives from medial dermomyotomal precursors (Ordahl and LeDouarin 1992), and is delayed by $\sim 2$ days (in both mice and chickens) in cells derived from the lateral dermomyotome (Buckingham 1992; Williams and Ordahl 1994).

It has been shown that signals from either the axial tissues (i.e., the neural tube and notochord) or the surface

${ }^{1}$ Corresponding author.

E-MAIL lassarab@warren.med.harvard.edu; FAX (617) 738-0516. ectoderm are capable of inducing the expression of Pax3 and somitic myogenesis in explants of paraxial mesoderm (Avery et al. 1956; Vivarelli and Cossu 1986; Kenny-M obbs and Thorogood 1987; Christ et al. 1992; Rong et al. 1992; Buffinger and Stock dal e 1994, 1995; Fan and Tessier-Lavigne 1994; Gamel et al. 1995; M ünsterberg and Lassar 1995; Stern and Hauschka 1995; Stern et al. 1995; Cossu et al. 1996; Spence et al. 1996). The combination of Wnt1 or Wnt3 plus Sonic hedgehog (Shh) can mimic the axial signals and induce expression of both Pax3 and somitic myogenesis (M ünsterberg et al. 1995; Maroto et al. 1997). In vivo, however, it appears that somitic myogenesis can be induced by both Shh-dependent and -independent pathways. Whereas mouse embryos genetical ly engineered to lack Shh display a significant reduction in the accumulation of M yf5 transcripts in the medial regions of the somite, somitic MyoD expression is not altered in these embryos (Chiang et al. 1996).

Additional evidence that several signals are involved in somitic myogenesis has come from an examination of the rol e of Pax3 in this process. Recently, we have shown that forced expression of Pax 3 in paraxial mesoderm can activate MyoD and M yf5 expression in the absence of inducing tissues ( $M$ aroto et al. 1997). M oreover, work by Buckingham and colleagues has shown that Pax3 is necessary for the activation of MyoD in the trunk of mouse embryos deficient for Myf5 (Tajbakhsh et al. 1997). 
Localized Noggin controls MyoD activation

Whereas these results would indicate that Pax3 expression is both necessary and sufficient to activate somitic myogenesis, there must exist in vivo additional constraints on the myogenic activity of Pax3. Whereas Pax3 is uniformly expressed in the epithelial dermomyotome, myogenesis per se is observed only in the small fraction of these cells that invaginate at the dorsomedial lip of this tissue (Denetclaw et al. 1997), indicating that the myogenic activity of Pax 3 is highly restricted within the dermomyotome. The factors that activate $M y o D$ and Myf5 in the dorsomedial lip of the dermomyotome and/ or delay the activation of these genes in the lateral dermomyotome have hitherto been unknown.

Prior work in Xenopus embryos has indicated that BM P signaling plays a crucial role in controlling the location of skeletal muscle formation in this species. The specification of mesoderm as either dorsal (i.e., notochord), lateral (i.e., skeletal muscle), or ventral (i.e., blood) is controlled by relative levels of BMP signaling within these embryonic domains. It has been shown that embryonic expression of Xenopus $M y o D$ or $M y f 5$ requires a specific level of BM P signal ing (Re'em-Kal ma et al. 1995; Dosch et al. 1997), which is regulated by BM P2, BM P4, and BM P7 expressed in ventral regions of the embryo, and BMP antagonists, such as Noggin, Chordin, and Follistatin, which are expressed in dorsal regions of the embryo (for review, see Harland 1994; Graff 1997; Sasai and De Robertis 1997; Wilson and HemmatiBrivanlou 1997). The position and extent of muscle formation in either Xenopus embryos or explants of embryonic tissue can be modulated by the ectopic expression of either BMP4 or Noggin (Smith et al. 1993; Re'emKalma et al. 1995; Dosch et al. 1997), indicating that myogenesis in this species requires a specific level of BMP signals and is inhibited by either an excess or absence of such signals.

In this study we evaluate the role that BMPs and the $\mathrm{BM} P$ antagonist $\mathrm{N}$ oggin may have in the regulation of somitic myogenesis in amniote embryos. By exposing explants of chick somites cultured with either the axial tissues or the overlying ectoderm to variable amounts of BMP4 or Noggin we have found that varying levels of BM $P$ signaling regulate differing aspects of somite patterning. Whereas high levels of BMP signaling can induce lateral plate gene expression in paraxial mesoderm, lower levels of BMP signaling within the somite control the ability of Pax3 positive cells to activate the expression of $M y o D$ and $M y f 5$. Consistent with this later observation, we show that Noggin is expressed within the dorsomedial lip of the dermomyotome, where Pax3 expressing cells first initiate the expression of $M$ yoD and Myf5 to give rise to myotomal cells in the medial somite. Ectopic expression of N oggin Iateral to the somite dramatically expands $M$ yoD expression into the lateral regions of the somite, represses Pax3 expression in this tissue, and induces formation of a lateral myotome. Together, our findings suggest that BMP signaling and localized expression of a BM P antagonist, N oggin, together control the timing and location of myogenesis within the somite.

\section{Results}

Signals from the ectoderm can activate somitic myogenesis in rostral but not caudal paraxial mesoderm and are distinct from axial signals

Different axial levels of paraxial mesoderm display differential competence to respond to the muscle-promoting activities of dorsolateral neural tube or Wnt1 producing cells: These axial signals induce myogenesis in somites IV-VI, but not in presegmented paraxial mesoderm isolated from stage 10 chick embryos (M ünsterberg and Lassar 1995; Münsterberg et al. 1995). [The most recently formed somite is termed stage I, and successively more rostral somites are termed stages II, III, etc. (Ordahl 1993; Christ and Ordahl 1995)]. As signals from the dorsal ectoderm can al so induce somitic myogenesis (Kenny-M obbs and Thorogood 1987; Cossu et al. 1996; Maroto et al. 1997), we investigated whether varying axial levels of paraxial mesoderm display a similarly differential response to inductive signals from the surface ectoderm. Whereas somites I-III fail to express either dermomyotomal Pax genes (Pax3 and Pax7) or myotomal markers (Myf5, MyoD, myogenin, and myosin heavy chain) when cultured with overlying ectoderm (Fig. 1, Iane 1), more rostral somites IV-VI or VII-IX cocultured with overlying ectoderm express both the dermomyotomal Pax genes and display robust myogenesis in vitro (Fig. 1, lanes 3,5). It seems likely that both Pax3/Pax7 and the various myotomal genes were expressed in the mesoderm in these tissue recombinants, as ectoderm cultured alone failed to express any of these transcripts (Maroto et al. 1997). When cultured in the absence of

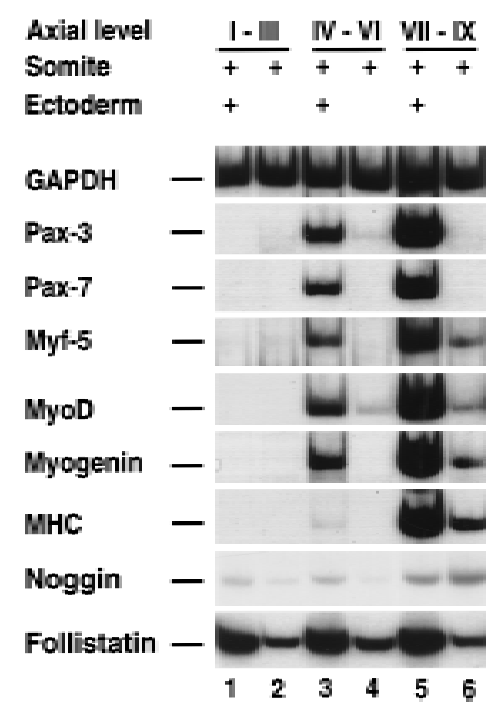

Figure 1. Signals from the surface ectoderm can activate somitic myogenesis in rostral but not in caudal paraxial mesoderm. Paraxial mesoderm isolated from differing axial levels of a stage 10 chick embryo was cultured for $72 \mathrm{hr}$ either in the absence (lanes $2,4,6)$ or in the presence (lanes 1,3,5) of overlying ectoderm. Gene expression was analyzed by RT-PCR. Similar results were obtained in at least 10 independent experiments. 
surface ectoderm for $72 \mathrm{hr}$, paraxial mesoderm from this stage chick embryo fails to maintain expression of Pax3 and Pax7 (M aroto et al. 1997) and displays either no detectable (in somites I-III) or relatively low levels (in somites IV-IX) of myogenic marker gene expression (Fig. 1 , lanes 2,4,6). These findings indicate that in stage 10 chick embryos there are rostral-caudal differences in either the inductive ability of the ectoderm to activate both dermomyotomal and myotomal markers in adjacent paraxial mesoderm, or the competence of the paraxial mesoderm to respond to these inducing signals.

Prior work has indicated that muscle-promoting signals from the dorsolateral neural tube and the ventral midl ine tissues (i.e., the notochord and fl oor plate) can be mimicked by Wnt and Shh signals, respectively (M ünsterberg et al. 1995). To address whether Shh and signals from the ectoderm might similarly cooperate to induce somitic myogenesis, we examined whether the addition of soluble Shh to cocultures of somites I-III and surface ectoderm would elicit myogenesis. Shh induced the expression of the sclerotomal marker Pax 1, but no myotomal markers in somites I-III cocultured with overlying ectoderm (Fig. 2, lane 3). In contrast, administration of Shh induced the expression of both Paxl and myotomal markers in somites cocultured with the adjacent dorsolateral neural tube (Fig. 2, lane 1). As Shh can activate somitic myogenesis in combination with signals from the dorsolateral neural tube, but not in combination with signals from the surface ectoderm, the muscle-promoting signals in the ectoderm appear functionally distinct from those in the neural tube.

BMP signals block myogenesis in somites I-III cocultured with overlying ectoderm

Pourquié and colleagues have noted previously that in

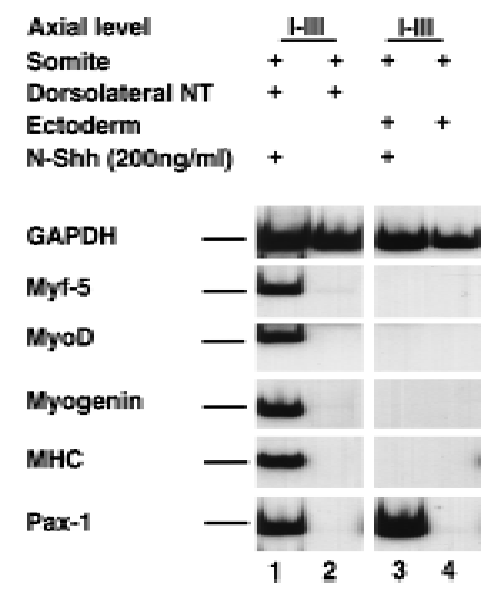

Figure 2. Signals from dorsolateral neural tube, but not from surface ectoderm induce myogenesis in caudal somites in the presence of Shh. Somites I-III isolated from a stage 10 chick embryo were cultured with either the adjacent dorsol ateral neural tube (lacking the floor plate; lanes 1,2 ) or with the overlying ectoderm (lanes 3,4$)$ in the presence (lanes 1,3 ) or absence (lanes $2,4)$ of $200 \mathrm{ng} / \mathrm{ml}$ of the amino-terminal fragment of Shh ( $\mathrm{N}$ Shh). Gene expression was analyzed by RT-PCR. Similar results were obtained in at least seven independent experiments. avian embryos, BMP-4 is highly expressed in both the dorsal-neural tube and I ateral plate mesoderm (Pourquié et al. 1996), and when ectopical ly expressed between the axial and paraxial tissues, can block somitic expression of MyoD (Pourquié et al. 1996). At stage 11, BMP4 is expressed at relatively higher levels in posterior regions of the embryo. Whereas presegmented mesoderm (psm) and somites I-III lie adjacent to lateral plate mesoderm expressing high levels of BM P4, somites rostral to these levels are exposed to relatively lower levels of BM P4 (Fig. $3 A$ ), raising the possibility that differential expression of BM P4 al ong the axis of stage 11 embryos might account for the differential ability of paraxial mesoderm plus ectoderm conjugates to initiate both dermomyotomal and myotomal gene expression in explant culture. To evaluate if BMP-like signals might restrain myogenesis in somites I-III cultured with overlying ectoderm, we cultivated this tissue in either the absence or presence of the BM P antagonist, N oggin. N oggin has been shown to bind to BMP2, BMP4, and BMP7, and thereby preclude interaction of these ligands with their cognate receptors (Zimmerman et al. 1996). M yotomal gene expression was substantially increased in somites I-III cocultured in the presence of ectoderm when these explants were exposed to supernatant from $\mathrm{C}$ hinese hamster ovary $(\mathrm{CHO})$ cells engineered to express N oggin (Fig. 4, lanes 1,3). In contrast, explants of somites I-III pl us ectoderm exposed to control $\mathrm{CHO}$ cell supernatant contained only trace levels of myogenic bHLH gene transcripts (Fig. 4, lane 2). Administration of N oggin to somites I-III in the absence of surface ectoderm failed to induce myogenesis (Fig. 4, lane 4). Consistent with the notion that $\mathrm{N}$ oggin induces myogenesis in somites I-III cultured with surface ectoderm by titration of BM P activity, we have found that the ability of N oggin to induce myogenesis in explants of these tissues was specifically bl ocked by incl usi on of 100 $\mathrm{ng} / \mathrm{ml}$ of BM P4 in the culture medium (data not shown). These findings indicate that the ability of ectoderm to induce myotomal markers in somites I-III is specifically restrained by BM $P$ ligands that are present within these tissues. This experiment does not distinguish whether the somite itself or neighboring tissues are the source of this BM P signal. However, because BM P4 is initially expressed in the overlying epidermal ectoderm (for review, see Watanabe and Le Douarin 1996; Schultheiss et al. 1997), and is subsequently expressed in both the lateral plate mesoderm and the dorsal regions of the neural tube (Fig. 3A; Liem et al . 1995; Pourquié et al. 1996), it seems likely that a potential source of BMP signals are these tissues that lie adjacent to the somite.

Varying BMP4 levels differentially affect Pax3 and MyoD induction by the ectoderm

In light of the ability of a BM P antagonist to activate myogenic markers in somites I-III cocultured with ectoderm, we investigated whether BMP4 administration would block myogenesis in more rostral somites (IV-IX) 


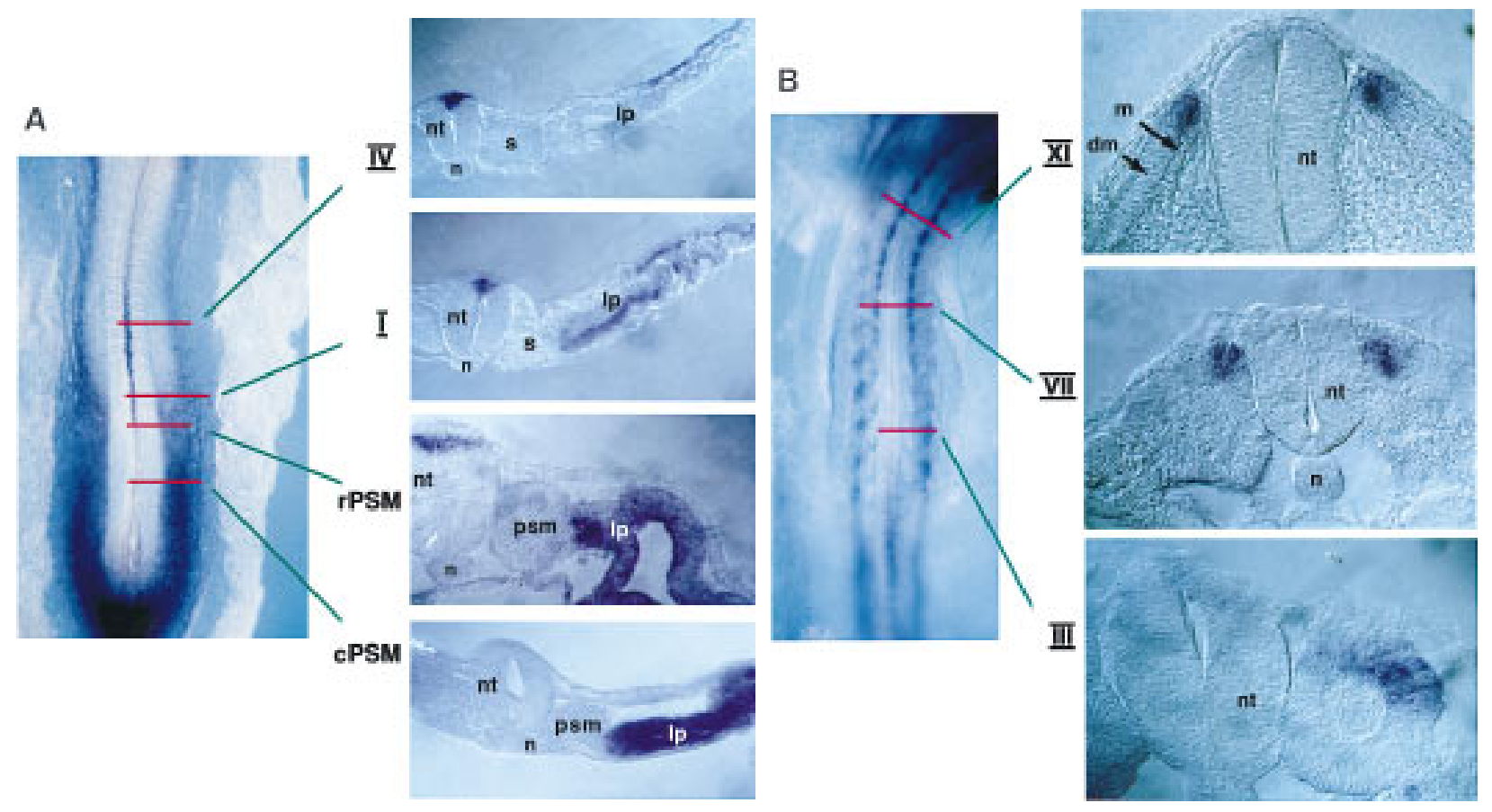

Figure 3. In situ hybridization analysis of BM P4 (A) and N oggin (B) gene expression. (A) A whole mount in situ hybridization of a stage 11 chick embryo displaying the expression of BM P4 transcripts. Transverse sections show the expression of BM P4 at the indicated axial levels in tissues adjacent to the paraxial mesoderm: lateral plate mesoderm at caudal levels and roof plate and dorsal ectoderm at more rostral levels. (B) A whole mount in situ hybridization of a stage 13 chick embryo displaying the expression of $\mathrm{N}$ oggin transcripts. Transverse sections show the expression of $\mathrm{N}$ oggin at the indicated axial levels. Lateral somitic expression of $\mathrm{N}$ oggin is observed in the psm and in newly formed epithelial somites, dorsomedial expression of $\mathrm{N}$ oggin can be detected rostral to somite III. (dm) Dermomyotome; (Ip) lateral plate; (m) myotome; (n) notochord; (nt) neural tube; (psm) presegmented mesoderm; (s) somite; (cPSM) caudal presegmented mesoderm; (rPSM) rostral presegmented mesoderm.

cocultured with ectoderm (Fig. 5). Administration of high levels of purified recombinant BM P4 (100 ng/ ml) to these explants blocked the expression of both dermo-

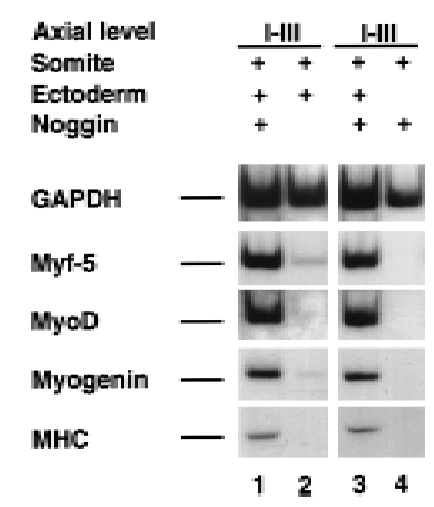

Figure 4. Alleviation of BMP signaling by Noggin induces myogenesis in caudal somites cultured with ectoderm. Somites I-III isolated from a stage 10 chick embryo were cultured with overlying ectoderm (lanes 1-3) or cultured al one (lane 4) either in the presence of medium condition by $\mathrm{N}$ oggin secreting $\mathrm{CHO}$ cells (lanes $1,3,4$ ) or medium conditioned by control $\mathrm{CHO}$ cells (lane 2). Gene expression was analyzed by RT-PCR. Similar results were obtained in at least eight independent experiments. myotomal (Pax3, Pax7, and Sim1) and myotomal (Myf5, MyoD, myogenin, myosin heavy chain) markers, increased the expression of GATA5 and induced that of GATA4 (Fig. 5A, lanes 1,3). GATA-4 and GATA-5 are two transcription factors that are highly expressed in the lateral plate (Laverriere et al. 1994). We think that GATA 4 and GATA 5 are being induced in the mesoderm in these explants, as these genes are induced in somites cultured al one with BM P4 (data not shown).

Interestingly, administration of $50 \mathrm{ng} / \mathrm{ml}$ of BMP4 abolished MyoD expression whereas that of Pax3 was only diminished (Fig. 5B, cf. lanes 3 and 4). Addition of $10 \mathrm{ng} / \mathrm{ml}$ of BMP4 to these cultures induced GATA 4 expression, but did not significantly affect either M yoD or Pax3 gene expression (Fig. 5B, cf. Ianes 5 and 6). From our analysis, it is not yet clear whether BM P signals act to modify the muscle-inducing ability of the ectoderm or the competence of the mesoderm to respond to these signals. However, because lower levels of BM P-signal ing preferentially inhibit MyoD induction by signals from the surface ectoderm while allowing the continued expression of Pax3, we feel that BM P signals directly affect the mesoderm. These findings suggest that differences in BMP levels can modulate whether ectodermal signals activate solely dermomyotomal markers (i.e., Pax3) or both dermomyotomal and myotomal genes. 


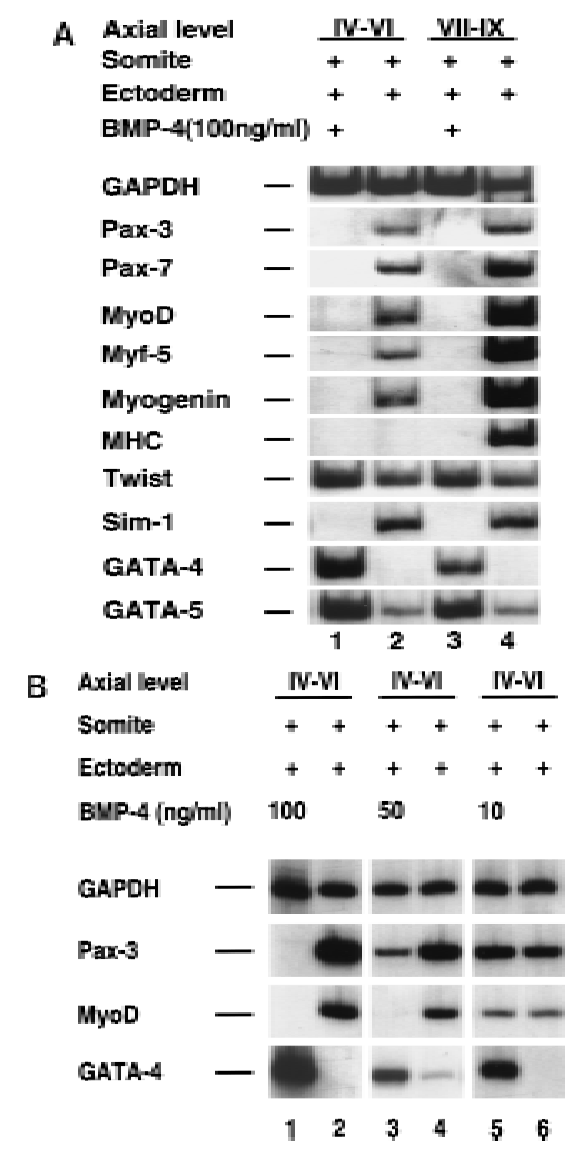

Figure 5. Varying BMP4 concentrations differentially affect the induction of Pax3 and MyoD in paraxial mesoderm by signals from the surface ectoderm. (A) Somites from the indicated axial level were isolated from a stage 10 chick embryo and cultured with overlying ectoderm in either the presence (lanes 1,3 ) or absence (lanes 2,4$)$ of $100 \mathrm{ng} / \mathrm{ml}$ BM P4. Similar results were obtained in at least 10 independent experiments. (B) Somites IV-VI were isolated from a stage 10 chick embryo and cultured with overlying ectoderm in either the absence (Ianes $2,4,6$ ) or presence (lanes $1,3,5)$ of increasing concentrations of BM P4 as indicated. Gene expression was analyzed by RT-PCR. Similar results were obtained in at least four independent experiments.

BMP signals block the muscle promoting activities of axial tissues downstream of Pax3 expression in paraxial mesoderm

In addition to monitoring how BM P4 administration affects somitic gene expression in response to ectodermal signals, we eval uated the effect of BM P4 on somitic gene expression in response to signals from the axial tissues. Coculture of somites I-III with neural tube and notochord results in robust expression of myogenic and sclerotomal (i.e., Pax1) markers (Fig. 6A, lane 2). Administration of $100 \mathrm{ng} / \mathrm{ml}$ BM P4 to these cultures results in the loss of all these markers and the up-regulation of the lateral plate marker, GATA4 (Fig. 6A, lane 1). Because Pax 3 is expressed in both the neural tube and the paraxial mesoderm, to eval uate whether BM P4 administra- tion affects the expression of Pax 3 in somitic cells in response to signals from the axial tissues, we combined

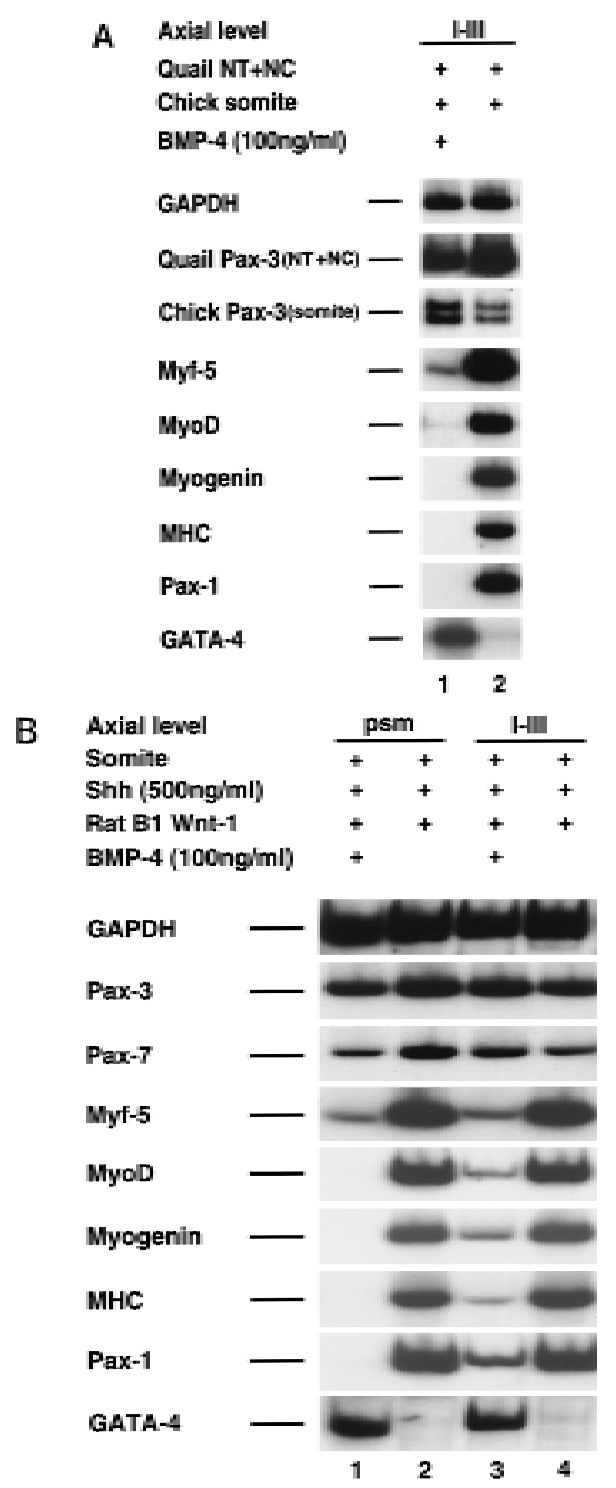

Figure 6. BM P4 blocks the muscle promoting activities of either the axial tissues or Wnt1 plus Shh downstream of Pax3 expression in paraxial mesoderm. (A) BMP4 blocks somitic myogenesis but not the induction of $\mathrm{Pax} 3$ or Pax7 by the axial tissues. Somites I-III were isolated from a chick embryo and recombined with neural tube and notochord isolated from the same axial level of a quail embryo and either cultured in the presence (lane 1 ) or absence (lane 2 ) of $100 \mathrm{ng} / \mathrm{ml}$ of BM P4. Gene expression was analyzed by RT-PCR. Chick and quail Pax3 PCR products were distinguished by a restriction enzyme polymorphism. Similar results were obtained in at least three independent experiments. (B) BM P4 blocks somitic myogenesis but not the induction of Pax3 or Pax7 by the combination of Wnt1 and Shh signals. Paraxial mesoderm from the indicated axial level was cultured in the presence of RatBla cells programmed to express Wnt1 (RatBla-Wnt1) plus $500 \mathrm{ng} / \mathrm{ml}$ of $\mathrm{N}$-Shh in either the presence (lanes 1,3) or absence (lanes 2,4) of $100 \mathrm{ng} /$ $\mathrm{ml}$ of BM P4. Gene expression was analyzed by RT-PCR. Similar results were obtained in at least four independent experiments. 
quail axial tissues with chick paraxial mesoderm. This cross-species induction assay allowed us to distinguish the effects of BMP4 administration on Pax3 levels in either the neural tube/ notochord (quail) versus Pax3 levels in the somite (chick). By employing RT-PCR analysis and a restriction site polymorphism between chick and quail Pax3 transcripts, we found that administration of $100 \mathrm{ng} / \mathrm{ml}$ of BM P4 efficiently blocks somitic myogenesis and causes a two- to threefold decrease in neural tube/notochord Pax3 expression, and approximately a threefold increase in somitic Pax3 expression (Fig. 6A, lane 1). These findings indicate that BMP4 signals can bl ock somitic myogenesis in response to signals from the axial tissues downstream of somitic Pax3 gene expression.

BMP signals block induction of myogenesis by Wnt and Shh signals downstream of Pax3 activation

Because the muscle-promoting signals from the neural tube and notochord can be mimicked by Wnt and Shh signals, respectively (M ünsterberg et al. 1995), we monitored whether somitic myogenesis induced by this combination of signals was similarly blocked by BM P4. Cocultivation of either psm or somites I-III from stage 10 chick embryos with soluble Shh and RatB1 cells programmed to express Wnt1 (RatB1-Wnt1) led to high level expression of both Pax3, Pax7, and myotomal markers (Myf5, MyoD, myogenin, myosin heavy chain; Fig. 6B; lanes 2,4). Whereas administration of $100 \mathrm{ng} / \mathrm{ml}$ of BMP4 significantly decreased accumulation of myotomal transcripts, somitic Pax3 and Pax7 gene expression was not significantly affected by this treatment (Fig. 6B; cf. lanes 1 with 2 and 3 with 4). This finding mirrors the effects of BMP4 on somitic gene expression in response to signals from the axial tissues (see above section), and indicate that BM P4 signaling blocks somitic myogenesis in response to Shh and Wnt1 signals downstream of Pax3 induction.

Noggin is expressed in the dorsal-medial lip of the dermomyotome

The differential activation of myogenic markers in rostral versus caudal explants of paraxial mesoderm cocultured with surface ectoderm, coupled with the ability of Noggin to elicit myogenesis in caudal explants from a stage 10 chick embryo, suggest that myogenesis is differentially suppressed by BM P signals al ong the A-P axis. Although it is clear that BM P4 is differentially expressed along the axis at this time of development, we wondered if differences in the expression of BM P antagonists along the axis might also contribute to the varying response of paraxial mesoderm to signals from the overlying ectoderm. We monitored the expression of both N oggin and Follistatin in somites explanted from different axial levels that had been cultured in either the absence or presence of overlying ectoderm (Fig. 1). Whereas expression of dermomyotomal Pax genes and myogenesis was observed only in rostral somites (IV-IX) cultured with ec- toderm, Follistatin expression was approximately equival ent in explants containing either caudal or rostral paraxial mesoderm and Noggin expression was slightly increased in more rostral explants (Fig. 1). Coculture of somites with ectoderm significantly increased Follistatin expression in these explants and slightly boosted N oggin expression in caudal explants, yet showed no affect on Noggin expression in more rostral explants. Although this experiment does not discriminate whether the up-regulated expression of Follistatin observed in somites cultured with ectoderm is caused by increased expression in somitic tissue, versus additional Follistatin expression contributed by the ectoderm, we feel that the former is more likely, given the absence of detectable Follistatin expression in the ectoderm in vivo (Amthor et al. 1996).

To evaluate the spatial pattern of $\mathrm{N}$ oggin expression we analyzed expression of this gene during chick embryogenesis, by whole mount in situ hybridization, and found that this gene is expressed in both the notochord and dorsal neural tube in caudal regions of a stage 13 embryo (data not shown), and in the somites in more rostral regions of this stage embryo (Fig. 3B). In the somite, Noggin is initially expressed in the lateral regions of the epithelial somite and is subsequently expressed in the dorsomedial lip of the dermomyotome in more rostral somites (Fig. 3B), in which the myotome is starting to form (Denetclaw et al. 1997). Together, these findings suggest that the differences in myogenic potential of caudal versus rostral paraxial mesoderm cocultured with ectoderm may reflect both varying levels of BMP expression (in the adjacent tissues) and varying spatial patterns of $\mathrm{N}$ oggin expression within the somite.

The myogenic potential of Pax3 is negatively regulated by BMP signals within the somite

The presence of Noggin in the dorsomedial lip of the dermomyotome is of particular interest because this is the site where Pax3-positive dermomyotomal cells give rise to MyoD-positive myotomal cells (Ott et al. 1991; Pownall and Jr. 1992; Barth and Ivarie 1994; Denetclaw et al. 1997). Pax3 has recently been shown to be both necessary to activate $M y o D$ expression in the trunk of mice embryos lacking M yf5; (T ajbakhsh et al. 1997), and sufficient to activate myogenesis in somites infected with retroviral-encoded Pax3 (Maroto et al. 1997). Because Pax3 expression is initially uniform throughout the dermomyotome, yet myogenesis is only observed in a small fraction of dermomyotomal cells that invaginate at the dorsomedial lip of this tissue (Denetclaw et al. 1997), the muscle-promoting activity of Pax3 must be repressed in the dermomyotome and specifically activated in cells that invaginate at the dorsomedial lip to form the myotome. Therefore, we investigated whether the expression of $\mathrm{Noggin}$ in this population of cells might act to trigger the myogenic potential of Pax3.

Paraxial mesoderm from differing axial levels of a stage 10 chick embryo was cocultured with ectoderm in either the presence or absence of soluble $\mathrm{N}$ oggin (Fig. 7). 


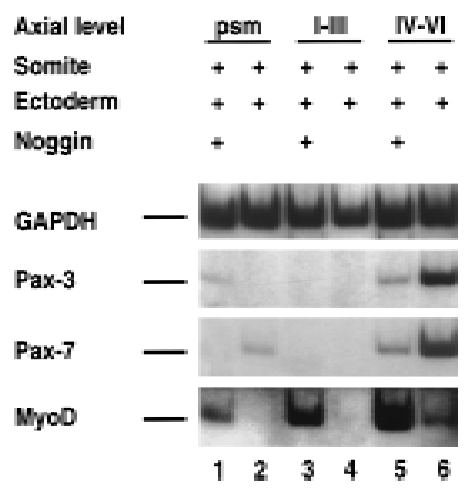

Figure 7. $B M P$ signals attenuate $M y o D$ induction by surface ectoderm at varying axial levels. Paraxial mesoderm was isolated from the indicated axial level and cultured with the overlying ectoderm in the presence of medium condition by $\mathrm{N}$ ogginsecreting $\mathrm{CHO}$ cells (lanes $1,3,5$ ) or medium conditioned by control CHO cells (lanes 2,4,6). Gene expression was analyzed by RT-PCR. Similar results were obtained in at least three independent experiments.

Either no detectable or only trace levels of Pax3, Pax7, and $\mathrm{M}$ yoD are expressed in psm or in somites I-III cocultured with ectoderm for $72 \mathrm{hr}$ (Fig. 7, lanes 2,4). As discussed previously, Noggin administration results in up-regulation of MyoD expression in this tissue (Fig. 7, lanes 1,3), which initially expressed low levels of Pax3 when first explanted (data not shown). In explants of more rostral somites IV-VI cocultured with ectoderm, Pax3 and Pax7 are highly expressed and MyoD is expressed at a relatively low level (Fig. 7, lane 6). Administration of $\mathrm{N}$ oggin to this more rostral explant up-regulated the expression of $\mathrm{MyoD}$ and depressed the expression of both Pax3 and Pax7 (Fig. 7, lane 5). Therefore, in explants of somites IV-VI plus ectoderm, the mesoderm maintains expression of Pax3 and Pax7 in response to ectodermal signals, but BMP signals sent by either the ectoderm, the lateral plate mesoderm, or the dorsal neural tube (see Discussion) apparently block efficient downstream activation of $M$ yoD. N oggi $n$ administration to these more rostral tissue explants relieves a blockade inhibiting MyoD gene expression and si multaneously reduces the expression of Pax3 and Pax7.

Ectopic Noggin administration in vivo expands MyoD expression within the dermomyotome

To evaluate whether endogenous BMP signaling blocks premature activation of $\mathrm{M}$ yoD in the dermomyotome in vivo, COS cell pellets transfected with either a N oggin expression vehicle or a control vehicle were implanted between the paraxial and lateral plate mesoderm, at the level of the psm, in a stage 10 chick embryo (diagrammed in Fig. 8A). The embryos were maintained in ovo for $\sim 15$ hr until the paraxial mesoderm adjacent to the implanted COS cells was at the position of somiteX. M yoD expression was subsequently analyzed by whole mount in situ hybridization (Fig. 8B,C). Implantation of $\mathrm{N}$ oggin secreting COS cells between the paraxial and lateral plate mesoderm induced a dramatic lateral expansion of MyoD gene expression in the somite relative to somites situated adjacent to control COS cells implanted on the contralateral side of the embryo (Fig. 8, B and C, cf. left and right sides of the embryo). A transverse section of these embryos indicated that the enhanced M yoD expression in these embryos correlated with the induction of a myotomal layer within the lateral somite (Fig. 8C). In contrast to the increased lateral expansion in $\mathrm{MyOD}$ expression, Pax3 expression was depressed in lateral re gions of the dermomyotome adjacent to the implanted Noggin producing COS cells (Fig. 8D,E). These results are consistent with the effects of $\mathrm{N}$ oggin on explants of paraxial mesoderm plus ectoderm, in which we observed a similar up-regulation of $\mathrm{M}$ yoD and depression of Pax3 gene expression (Fig. 7). These findings indicate that blockade of BMP signaling in the somite, by placement

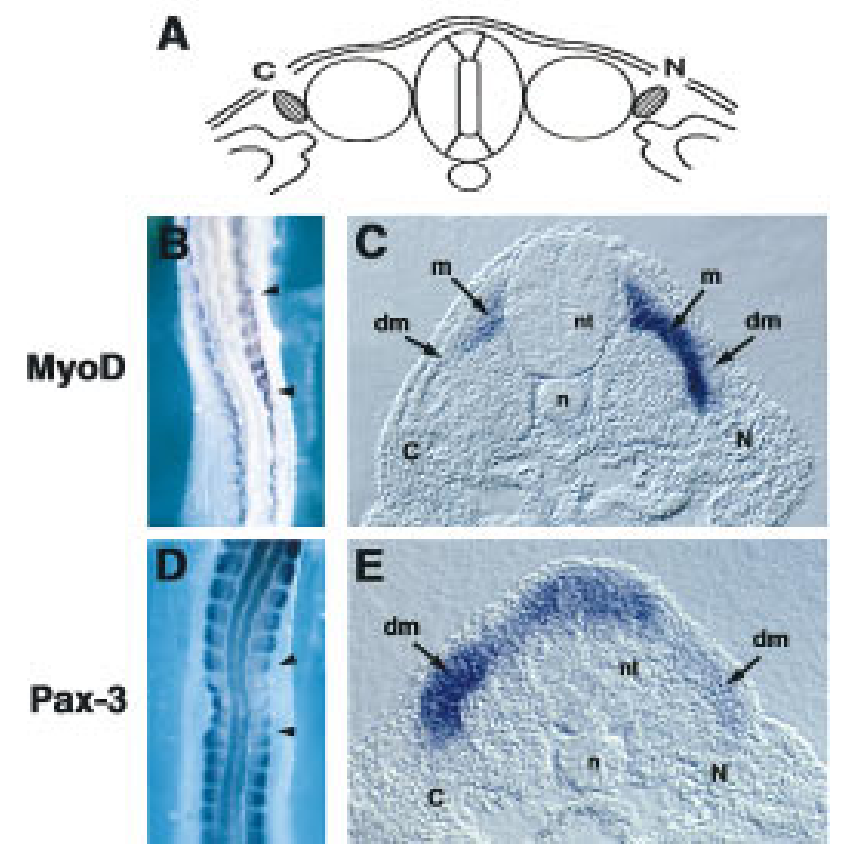

Figure 8. Alleviation of $\mathrm{BM} P$ signals by $\mathrm{N}$ oggin expands $\mathrm{M}$ yoD expression within the dermomyotome. Implantation of $\mathrm{N}$ ogginexpressing COS cells between the paraxial and lateral plate mesoderm leads to the expansion of $\mathrm{M}$ yoD expression in the lateral regions of the dermomyotome and down-regulation of Pax3 expression in this domain. COS cells transfected with either a $\mathrm{N}$ oggin expression vehicle or a control vehicle were implanted between the presegmental plate and lateral plate mesoderm of a stage 10 chick embryo. Noggin ( $\mathrm{N}$ )-transfected cells were implanted on the right side and control (C)-transfected COS cells were implanted on the left side of the operated embryo (position of COS cell pell lets diagrammed in A). The embryo was al lowed to develop in ovo for $15 \mathrm{hr}$ until the implanted COS cells were approximately adjacent to somite X. Whole mount in situ hybridization was performed for $M$ yoD $(B, C)$ and Pax3 $(D, E)$. (dm) Dermomyotome; $(\mathrm{m})$ myotome; $(\mathrm{n})$ notochord; $(\mathrm{nt})$ neural tube. Similar results were obtained in at least six independent experiments. 
of Noggin producing cells lateral to the paraxial mesoderm, can specifically expand MyoD expression, which is normal ly initiated in medial regions of the dermomyotome, into the lateral regions of this tissue. Concurrent with a lateral expansion of MyoD expression, Pax3 expression is decreased in the dermomyotome adjacent to the $\mathrm{N}$ oggin-producing COS cell pellet.

\section{Wnt1 signals are sufficient to induce somitic Noggin expression}

Separation of the somite from the adjacent axial tissues in ovo leads to loss of somitic Noggin expression ( $R$. Reshef and A.B. Lassar, data not shown). Because N oggin is expressed in cells at the dorsomedial lip of the dermomyotome that lie adjacent to the dorsal neural tube, we investigated whether any Wnt family members expressed in this region of the neural tube might be sufficient to induce somitic Noggin expression. Whereas Noggin is not expressed in somites I-III cultured with control fibroblasts (Rat B1 cells) for 5 days (Fig. 9, Iane 2), coculture of somites I-III with Wntl expressing fibroblasts (Rat B1-Wnt1 cells) led to robust N oggin expression (Fig. 9, lane 1). As we have reported previously (M ünsterberg et al. 1995; M aroto et al. 1997), Wnt1 signals, alone, were unable to induce $M$ yoD expression in this tissue, however, were able to do so in the presence of Shh (Fig. 9, cf. Ianes 1 and 3). Interestingly, coculture of somites I-III with ectoderm did not lead to accumulation of N oggin transcripts (Fig. 9, lane 5). These results suggest that Wnt1 (or a Wnt1-like signal) from the dorsal neural tube is sufficient to induce $N$ oggin expression in the dorsomedial lip of the dermomyotome.

\section{Discussion}

Differing levels of BM P4 signaling seem to modulate sev-

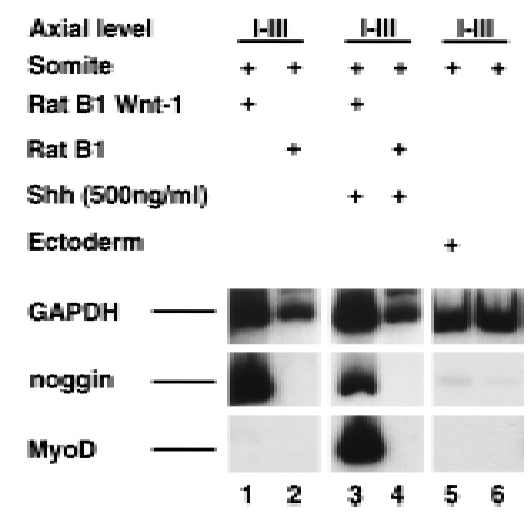

Figure 9. Wntl signals are sufficient to induce somitic N oggin expression. Somites I-III from a stage 10 chick embryo were cultured either in the presence of RatBla cells programmed to express Wnt1 (RatBla-Wnt1; lanes 1,3) or the parental RatBla cells (lanes 2,4$)$, in either the absence (lanes 1,2 ) or presence (lanes 3,4 ) of $500 \mathrm{ng} / \mathrm{ml}$ of $\mathrm{N}$-Shh. In addition, somites I-III were cultured with either overlying ectoderm (lane 5) or al one (lane 6). Gene expression was analyzed by RT-PCR. Similar results were obtained in at least three independent experiments. eral sequential events during somite maturation. High levels of BM $P$ signals serve to establish a boundary be tween paraxial and lateral plate mesoderm (Dosch et al. 1997; N eave et al. 1997; Tonegawa et al. 1997, and references therein). Lower levels of BM P4 signals in the lateral somite work in combination with ectodermal signals (Fan and Tessier-Lavigne 1994) to activate expression of Sim-1 in the lateral dermomyotome (Pourquié et al. 1996; Tonegawa et al. 1997) and up-regulate Pax3 expression in this tissue (Pourquié et al. 1996). In this work, we show that differing levels of BM P signaling can selectively modulate whether signals from the axial tissues or the surface ectoderm activate the expression of either Pax3 or the myogenic bHLH factors in the adjacent paraxial mesoderm. Whereas induction of Pax3 in paraxial mesoderm by either the axial tissues or the combination of Wntl and Shh signals is relatively unaffected by the addition of BM P4 (up to $100 \mathrm{ng} / \mathrm{ml}$ ), activation of the myogenic bHLH regulators is significantly reduced by this treatment (Fig. 6A,B). In contrast, induction of dermomyotomal Pax3 by the overlying ectoderm is extinguished by high level s of BM P4 (100 ng/ml) but maintained in the presence of l ower levels of BM P4 $(50 \mathrm{ng} / \mathrm{ml})$ that are sufficient to extinguish MyoD expression (Fig. 5B). Conversely, administration of the BMP antagonist, $\mathrm{N}$ oggin, to paraxial mesoderm cocultured with ectoderm dramatically up-regulates the expression of $M y o D$ and Myf5 (Figs. 4 and 7). We have found that Noggin is expressed at the dorsomedial lip of the dermomyotome, where Pax3-positive cells initiate the expression of MyoD and Myf5, and that somitic Noggin expression can be induced by Wntl that is expressed in the dorsal neural tube. Furthermore, we show that implantation of Noggin-producing COS cells between the paraxial and lateral plate mesoderm induces high-level expression of $M$ yoD in the lateral somite, depresses Pax3 expression in this somitic domain, and induces promiscuous formation of a laterally situated myotome (Fig. 8). Together, these findings indicate that BMP signals block the activation of $M y o D$ and $M y f 5$ in Pax3-expressing dermomyotomal cells and that myogenesis within these cells may be specifically derepressed at the dorsomedial lip of the dermomyotome by the presence of the BM P-antagonist $\mathrm{N}$ oggin (summarized in Fig. 10A).

Induction of MyoD by Pax3 is blocked by BMP signals and activated by regionalized expression of BMP antagonists

Forced expression of Pax3 in vitro can activate both $M y o D$ and $M$ yf5 expression in somitic tissue ( $M$ aroto et al. 1997). In vivo, however, Pax3-expressing dermomyotomal cells lack expression of either myogenic bHLH regulator (Goulding et al. 1994; Williams and Ordahl 1994; Marcelle et al. 1995), indicating that the musclepromoting properties of Pax3 must be highly regulated within the paraxial mesoderm. In this work we show that administration of exogenous BMP4 can uncouple the induction of Pax3 from the induction of somitic myogenesis by signals from either the ectoderm or the 


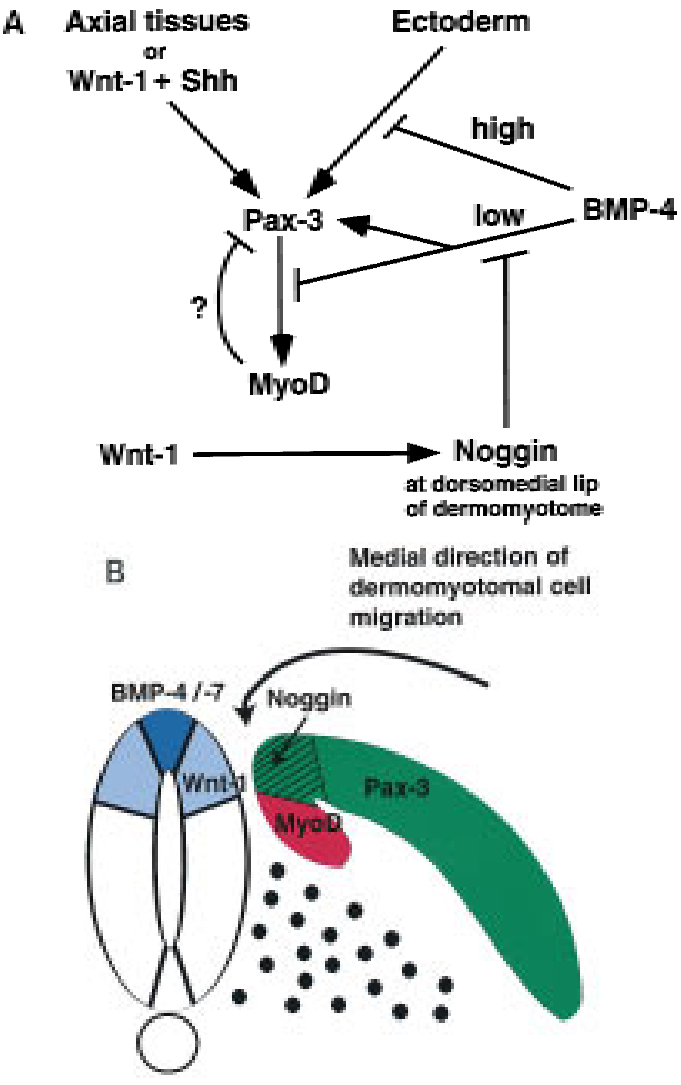

Figure 10. (A) Diagram of regulatory networks controlling somitic expression of Pax 3 and $M y o D$. Combinatorial signals from the dorsolateral neural tube and floor plate/notochord or signals from the surface ectoderm activate Pax 3 expression and, subsequently, Pax3 induces MyoD. We speculate that high levels of BMP signals in lateral plate mesodermal tissue serve to block the induction of Pax3 in this tissue by signals from the surface ectoderm. In contrast, in somitic tissue, lower levels of BMP signaling are both necessary to maintain Pax3 expression in response to signals from either the axial tissues or the surface ectoderm and to block MyoD expression within the dermomyotome. Potential sources of these BMP signals are the epidermal ectoderm that overlies the invaginating paraxial mesoderm and expresses BMP4 and BMP7 (Liem et al. 1995; Schultheiss et al. 1997); the lateral plate mesoderm that expresses BM P4 (Pourquié et al. 1996); the dorsal neural tube that expresses BMP2, BMP7, and Dorsalin (Liem et al. 1995); the mesonephric duct that expresses BMP2 (R. Reshef, M. Maroto, and A.B. Lassar, data not shown); and the dermomyotome of mature somites that expresses BM P4 (A. M CM ahon, pers. comm.) and BM P2 in the dorsomedial lip of this tissue (R. Reshef, M. Maroto, and A.B. Lassar, data not shown). Our data suggests that Wnt signals sent from the dorsal neural tube induce $\mathrm{N}$ oggin expression at the dorsomedial lip of the dermomyotome, and that N oggin acts in combination with other BMP antagonists expressed within the somite (i.e., Follistatin) to relieve a BMP-mediated inhibition of MyoD expression and thereby initiates $\mathrm{MyoD}$ expression and myotome formation. For simplicity, Myf5 is not shown in this diagram; however, our data indicate that BM P signals similarly repress the expression of $M$ yf5 by signals from either the axial tissues or the surface ectoderm. (B) Diagram of the domains of dermomyotomal gene expression. The somitic expression domains of Pax3, N oggin, and M yoD are indicated within the dermomyotome, the dorsomedial lip of the dermomyotome, and the myotome, respectively. Also diagrammed is the expression domain of BMP4, BMP7, and Wnt1 in the neural tube. axial tissues. Addition of high $(100 \mathrm{ng} / \mathrm{ml})$ or intermediate $(50 \mathrm{ng} / \mathrm{ml})$ levels of BM P4 to somites cultured with either the axial tissues or overlying ectoderm, respectively, can block the induction of MyoD without eliminating Pax3 expression in the paraxial mesoderm. Although increasing levels of BM P4 administration to somite/ ectoderm explants does decrease dermomyotomal Pax3 expression and eventual ly extinguishes expression of this gene (see Fig. 5B), the important finding in this work is that the expression of MyoD is more readily inhibited by BMP signals than that of Pax3.

That endogenous BM P signals block the expression of both MyoD and Myf5 in paraxial mesoderm in vivo is supported by our finding that N oggin is expressed in the dorsomedial lip of the dermomyotome, where Pax3 positive cells first initiate expression of myogenic bHLH transcription factors (Denetclaw et al. 1997), and that administration of exogenous $\mathrm{N}$ oggin can boost the expression of myogenic bHLH genes in paraxial mesoderm cocultured with surface ectoderm. Furthermore, implantation in vivo of a pellet of COS cells programmed to express $\mathrm{N}$ oggi in inserted between the paraxial mesoderm and the lateral plate induces a dramatic up-regulation of MyoD expression in the lateral regions of the somite with a simultaneous induction of a lateral myotome. Together, these findings suggest that the myogenic promoting activity of Pax 3 is specifically restrained within the dermomyotome by BM P signaling.

Interestingly, chick dermomyotomal cells express at least two distinct BM P-antagonists, N oggin in the dorsomedial domain (this work), and Follistatin in both the dorsomedial and ventrolateral domains (Amthor et al. 1996). In contrast, chick somites lack expression of chordin, which is expressed in Hensen's node and the notochord (data not shown; K. Lee and T. Jessell, pers. comm.). We speculate that expression of N oggin in the dorsomedial quadrant of the dermomyotome acts in combination with Follistatin and perhaps with other BM P antagonists, that is, Flik (Amthor et al. 1996) expressed within the somite to negate BMP signaling and thereby activate M yoD and M yf5 expression in the dorsomedial lip of the dermomyotome (schematical ly outlined in Fig. 10B). Interestingly, placement of Nogginsecreting COS cells between the paraxial and lateral plate mesoderm induced MyoD expression only in the paraxial mesoderm and not in the adjacent lateral plate mesoderm, suggesting that Pax3 expressing cells of the dermomyotome are uniquely competent to activate the myogenic program when exposed to this BM P-antagonist. Further support for the notion that N oggin expression is crucial for the proper formation of the myotome has been obtai ned in mice engineered to lack $\mathrm{N}$ oggin. In Noggin-deficient mice embryos, the epaxial musculature, which is derived from the medial regions of the somite (Ordahl and Le Douarin 1992), is largely absent in the posterior of the embryo (A. MCM ahon and R. Harland, pers. comm.). Furthermore, Follistatin-deficient mice embryos exhi bit a decreased mass of the diaphragm and intercostal muscles (M atzuk et al. 1995), suggesting that this BM P-antagonist al so plays an important role in muscle formation in this species. 
N oggin administration to somites IV-VI cultured with overlying ectoderm augmented the expression of $M$ yoD and simultaneously repressed the expression of Pax3 and Pax7 (Fig. 7). Similarly, implantation of a pellet of $\mathrm{N}$ oggin-producing COS cells between the paraxial and Iateral mesoderm in ovo induced a lateral expansion of $M y o D$ expression and repressed the expression of Pax3 in this somitic domain (Fig. 8). The down-regulation of Pax3 gene expression in the paraxial mesoderm, subsequent to either implantation of $\mathrm{N}$ oggin-producing cells between the paraxial and lateral plate mesoderm (this work) or separation of these two tissues (Pourquí et al . 1995), may either reflect a direct requirement for BMP signals to maintain the expression of $\mathrm{Pax} 3$, or to an indirect repression of Pax3 by signaling molecules sent from the newly induced myotome (diagrammed schematically in Fig. 10A).

Induction of Pax3 and somitic myogenesis in response to signals from the axial tissues or the surface ectoderm display differing requirements for Shh

In vitro experiments with mouse and chick somites have indicated that both the axial tissues and the surface ectoderm are capable of inducing the expression of both dermomyotomal and myotomal genes in cocultured paraxial mesoderm (A very et al. 1956; Vivarelli and Cossu 1986; Kenny-Mobbs and Thorogood 1987; Christ et al. 1992; Rong et al. 1992; Buffinger and Stockdale 1994, 1995; Fan and Tessier-Lavigne 1994; Gamel et al. 1995; M ünsterberg and Lassar 1995; Stern and Hauschka 1995; Stern et al. 1995; Cossu et al. 1996; Spence et al. 1996). Myogenesis can be induced in somites IV-IX isolated from a stage 10 chick embryo when explanted with either the dorsolateral neural tube or the surface ectoderm. In contrast, in less mature somites I-III, signal s from the dorsolateral neural tube can only induce myogenesis in combination with soluble Shh (M ünsterberg et al. 1995), and ectodermal si gnals are unable to el icit myogenesi in this tissue either al one or in the presence of soluble Shh. Ectodermal signals do, however, initiate myogenesis in somites I-III isol ated from this stage embryo in the presence of the BMP inhibitor, N oggin. These findings suggest that the muscle-promoting signals from the axial tissues and the surface ectoderm are molecularly distinct from one another. At present, it is not clear whether this distinction reflects either a qualitative or quantitative difference between the muscle-inducing signals in these two tissues. Because the dorsolateral neural tube was able to induce myogenesis in somites I-III in combination with a Shh signal, whereas signals from the surface ectoderm activated myogenesis in this tissue only in the presence of Noggin, we suggest that signals from the surface ectoderm serve to maintain somitic myogenesis independently of Shh. These findings are consistent with the finding that mice engineered to lack Shh display a significant reduction in the accumulation of $\mathrm{M}$ yf5 transcripts in the medial regions of the somite, but somitic MyoD expression is not altered in these embryos (Chiang et al. 1996). Together, these findings indicate that there are Shh-dependent and Shh-independent pathways to activate somitic myogenesis in vertebrates.

BMP blocks paraxial mesoderm fates and differentially inhibits induction of Pax3 expression by axial and ectodermal signals

Consistent with findings in Xenopus, zebrafish and avian embryos which indicate that levels of BM P signaling control mesodermal cell fate (Dosch et al. 1997; N eave et al . 1997; T onegawa et al. 1997), we have found that administration of BM P4 to explants of paraxial mesoderm blocks the induction of paraxial mesodermal gene expression in this tissue in response to ectodermal signals. In this study, we show that administration of high levels of BM P4 $(100 \mathrm{ng} / \mathrm{ml})$ can block both myogenesis and the expression of dermomyotomal Pax genes (i.e., Pax3 and Pax7) in somites IV-IX conjugated with ectoderm. In contrast, this same amount of BM P4 inhibits somitic myogenesis but does not block the induction of Pax3 or Pax7 in the paraxial mesoderm in response to signals from either the neural tube/notochord complex or the combination of Wntl and Shh, which together mimic the muscleinducing signals of the axial tissues. These findings indicate that the induction of dermomyotomal Pax gene expression by signals from either the axial tissues or the surface ectoderm displays differing sensitivities to BMP4 signaling. This type of circuitry ensures that induction of $\mathrm{Pax} 3$ and Pax7 in the dermomyotome by signals sent from the axial tissues, or expression of these genes in the neural tube itself, is not abrogated by BMP4-like signals emitted by the dorsal neural tube, that is, BM P4, BM P7, and Dorsalin (Basler et al. 1993; Liem et al. 1995). Moreover, induction of Pax3 and Pax 7 by signal s from the overlying ectoderm may be specifically inhibited by high levels of BM P4 expression in lateral plate tissue. In this manner, differential BM P4 levels in lateral versus paraxial mesoderm may thereby act to confine the induction of Pax3 and Pax7 by ectodermal signals to only the paraxial mesoderm. It is presently unclear whether BMP administration inhibits paraxial mesodermal gene expression in response to ectodermal signals by al tering the inducing properties of the ectoderm, the competence of the mesoderm to respond to these signals, or both the inducing and responding properties of these tissues. However, because the induction of Pax1 in paraxial mesoderm by either ventral midline tissues or by purified recombinant Shh is also inhibited by the addition of exogenous BM P4 to this tissue (see Fig. 6A,B), it is clear that the competence of the mesoderm to respond to at least Shh must be altered by BMP administration.

Antagonistic activity between BMP4 and Noggin may serve to regional ize lateral somitic gene expression

Recently, Pourquié and colleagues have suggested that BM P4, which is expressed in the lateral plate mesoderm, augments Pax3 and Sim1 expression in the lateral aspect of the dermomyotome (Pourquié et al. 1996). These 
workers showed that implantation of cells programmed to express BMP4 between the neural tube and paraxial mesoderm, induced expression of Sim1, a lateral dermomyotomal marker, in the medial regions of the dermomyotome (Pourquié et al . 1996). Moreover, these workers found that a signal secreted by the axial tissues was necessary to suppress the expression of Siml in the medial dermomyotome (Pourquié et al. 1996). The presence of $\mathrm{N}$ oggin in the dorsomedial lip of the dermomyotome is consistent with this model, as this BMP antagonist may act to block BMP signals in the medial aspect of the dermomyotome and thereby preclude Sim1 expression from this region of the somite. An activity secreted by the axial tissues was shown to block Siml expression in the medial dermomyotome (Pourquié et al. 1996). Although the identity of this axial inhibitor of Sim1 expression is unknown, it seems likely that this inhibitor may either be $\mathrm{N}$ oggin, expressed in the roof plate of the neural tube, or may be a signal sent by the neural tube that induces $\mathrm{N}$ oggin expression in the dorsomedial lip of the dermomyotome. Consistent with this latter scenario, we have found that expression of Noggin within the dorsomedial lip of the dermomyotome requires signals from the adjacent axial tissues in ovo (data not shown), and that cocultivation of somites with fibroblasts programmed to express Wnt1, which is expressed in the dorsal neural tube, dramatically increases $\mathrm{N}$ oggin expression in the somitic tissue (Fig. 9). Together, these findings suggest that Wnt1 (or a Wnt1-like signal) in the dorsal neural tube is sufficient to induce $\mathrm{N}$ oggin expression in the dorsomedial lip of the dermomyotome.

Differing levels of BMP4 signaling appear to modulate several sequential events during somite maturation

Our findings indicate that after BM $P$ signals are used to establish a boundary between paraxial and lateral plate mesoderm (Dosch et al. 1997; Neave et al. 1997; Tonegawa et al. 1997, and references therein), these signals are again used to selectively modulate whether signals from the axial tissues or the surface ectoderm activate the expression of either Pax3 or the myogenic bHLH factors in the adjacent paraxial mesoderm. Basal levels of BM P signaling within the somite act to preclude the promiscuous activation of $M y o D$ in the dermomyotome, and the spatially restricted expression of the BMP antagonist N oggin in the dorsomedial lip of the dermomyotome may effect activation of the myogenic program in Pax3-positive cells within this tissue.

Because N oggin has been reported to block the activities of several BMP family members, including BMP2, BM P4, and BM P7 (Zimmerman et al . 1996), it is formally possible that these or other BM Ps are blocking myogenic bHLH gene activation in the dermomyotome. In chicken embryos, BMP4 is expressed during gastrulation stages in the epiblast and in the epidermal ectoderm that initially overlies the presumptive paraxial and lateral plate mesoderm, and subsequently, is expressed during early stages of somite formation in both the dorsal neural tube and in the lateral plate mesoderm (Fig. 3A; Pourquié et al. 1996; Watanabe and Douarin 1996; Schultheiss et al. 1997). These various domains of BMP4 expression are consistent with the findings of others that signals from the lateral plate mesoderm (Pourquié et al. 1995), the dorsal neural tube (Buffinger and Stockdale 1995), or the surface ectoderm (K. Patel, B. Christ, and H. Amthor, pers. comm.) can each inhibit somitic myogenesis. BM P7 is also expressed initially in the epidermal ectoderm and, subsequently, in the dorsal neural tube (Liem et al. 1995; Schultheiss et al. 1997). Administration of BM P7 can also block myogenesis in somites cocultured with neural tube and notochord (R. Reshef and A.B. Lassar, data not shown), suggesting that this BMP family member may also have a role in blocking somitic myogenesis. Interestingly, as somites continue to mature, BM P4 is expressed within the dermomyotome (A. McMahon, pers. comm.) and BM P2 is expressed within the dorsomedial lip of this tissue (R. Reshef, M. Maroto, and A.B. Lassar, data not shown). Thus, at early somitic stages, BMP4, BMP7, and perhaps other BM P family members expressed initially in either the epidermal ectoderm, the dorsal neural tube, or the lateral plate mesoderm, act to block MyoD and Myf5 activation within the dermomyotome. Subsequently, when the somite has increased in size and, thus, some dermomyotomal cells lie at an increased distance from these adjacent tissues, expression of BMP2 and BMP4 within the somite itself may act to maintain a nondifferentiated dermomyotomal stem cell population by repressing myogenesis within this tissue.

The signaling properties of the dorsal neural tube are complicated, as this tissue expresses both Wnt family members (Wnt1 and Wnt3), which can induce somitic $\mathrm{N}$ oggin expression (this report) and in combination with Shh signals can induce the expression of somitic Pax3 (M ünsterberg et al. 1995 ; Stern et al. 1995), and BM P4 and BM P7, which can block activation of myogenesis in Pax3-positive cells (this report and data not shown). The expression of both Wnt1/Wnt3 and BM P4/BM P7 in the dorsal-neural tube may account for the paradoxical findings that signals from this tissue have been reported to either activate (Stern et al. 1995) or inhibit (Buffinger and Stockdale 1995) somitic myogenesis in vitro. Furthermore, the fact that BM $P$ signals are required to maintain robust levels of Pax3 expression in the dermomyotome (Pourquié et al. 1996; this report; Fig. 8), indicates that BMP signals (emitted by either the dorsal neural tube, the surface ectoderm, or the lateral pl ate mesoderm) may serve to both promote somitic Pax3 expression and simultaneously repress activation of $M$ yoD and $M y f 5$ by this transcription factor ( $M$ aroto et al. 1997; diagrammed in Fig. 10A).

In concert with findings that BMP signals play a crucial role in controlling the onset of $M$ yoD expression in the axial musculature (this work; Pourquié et al. 1996), others have found that the onset of $M$ yoD expression in the limb is similarly controlled by BMP signals. Amthor and colleagues have found that $M$ yoD expression in the limb is negatively regulated by BMPs expressed in the limb bud ectoderm and that $M$ yoD is activated adjacent 
to N oggin-producing cells located within the core of the limb (K. Patel, B. Christ, and H. Amthor, pers. comm.). Together with our findings, these results indicate that both axial and appendicular muscle differentiation is negatively regulated by BM $\mathrm{P}$ signaling.

\section{Materials and methods}

Noggin containing medium, plasmids, and COS cell transfection

Noggin-conditioned medium and control medium were harvested from $\mathrm{CHO}$ cells stably expressing Xenopus Noggin (Lamb and Stahl 1993) or from nontransfected CHO cells. The $\mathrm{CHO}$ line was kindly provided by R. Harland (University of California, Berkeley). Noggin or control-conditioned media were each mixed in a 1:1 ratio with the explant culture medium and replaced every 2 days. CS2-N oggin plasmid (Zimmerman et al. 1996) was used to li potransfect COS-7 cells. The transfection was performed as essentially described in Roelink et al. (1994) with the following modification: $5 \mathrm{hr}$ after transfection the medium was replaced by Dulbecco's modified Eagle medium (DMEM) containing 10\% FBS and 1\% Penicillin/streptomycin. Twenty-four hous later, cells were removed and transferred to a petri dish coated with 1\% agar in Tyrode's solution and incubated for another $24 \mathrm{hr}$ to obtain small aggregates. Aggregates of 50-100 $\mu \mathrm{m}$ in diameter were used for transplantation.

\section{Explant culture and in ovo manipulations}

Embryos were incubated at $37.5^{\circ} \mathrm{C}$ and staged according to Hamburger and Hamilton (1951). Embryonic tissues were isolated and cultured as described in Münsterberg et al. (1995). Coculture of paraxial mesoderm with Wnt1-producing cells and the amino terminus of Shh (N-Shh) was performed as described in Münsterberg et al. (1995). In ovo surgical experiments were performed as described in Pourquié et al. (1995).

\section{Whole mount in situ hybridization}

The procedure was performed essentially as described in Wilkinson (1993) with the indicated modifications. Digoxigenin-labeled Noggin RNA probe was synthesized from Bluescript SK (+) by cutting with Xho and transcribing with T 3 RN A polymerase (antisense). Other digoxigenin-labeled RNA probes (BM P4, M yoD, and Pax3) used as described previously (Johnson et al. 1994; Liem et al. 1995). Embryos were treated with 10 $\mu \mathrm{g} / \mathrm{ml}$ of proteinase $\mathrm{K}$ (sigma) for $30 \mathrm{~min}$. Probe concentration in the hybridization mix was $\sim 0.2 \mu \mathrm{g} / \mathrm{ml}$. The alkaline phosphatase reaction was devel oped for $45 \mathrm{~min}$ (Pax3) to $4 \mathrm{hr}$ (BM P4). Sectioning and photography methods were performed as described in Schultheiss et al. (1995).

\section{RT-PCR Analysis}

RT-PCR analysis was performed essentially as described by $M$ aroto et al. (1997) and M ünsterberg et al . (1995). After production of CDNA by reverse transcriptase, single PCR reactions were performed with appropriate primer pairs for the designated genes. After individual PCR reactions were run, radiolabeled PCR transcripts were visualized by gel el ectrophoresis and autoradiography. Each PCR cycle was $93^{\circ} \mathrm{C}$ for $30 \mathrm{sec}, 60^{\circ} \mathrm{C}$ for 35 sec, and $72^{\circ} \mathrm{C}$ for $1 \mathrm{~min}$. Pax 1 , Pax3, Noggin, Shh, Follistatin, and GATA 4 were amplified in the presence of $5 \%$ formamide with an annealing temperature of $50^{\circ} \mathrm{C}$. We used 24 cycles to assay GAPDH and 30-32 cycles to assay other genes. The prim- ers used for PCR amplification were as described in M aroto et al. (1997) and as follows: Twist (D. Spicer, unpubl., 5'GCAGAGCGACGAGCTGGACTC and 5'-TGTTATCTAGGGCTCTTGCCGG (150 bp); Sim1 (Pourquié et al. 1996), 5'-CGGACTAGGCGGGAGAAAGA and 5'-TGGCTGGTGCGGCTGGAGTG (188 bp); GATA-4 (Laverriere et al. 1994), 5'-CTCCTACTCCAGCCCTTACC and 5'-GCCCTGTGCCATCTCTCCTC (224 bp) and GATA-5 (Laverriere et al. 1994), 5'CCAGCCCCTACCCCGCCTAC and 5'-CCCCGCAGTTCACGCACTCC (180 bp). Follistatin, (Graham and Lumsden 1996) 5'-TGGGAAGAAATGTAAAATGA and 3'-CTCGCTCGGATAAGTTGTGT (577 bp); N oggin, sequence kindly provided by R. Johnson (University of Texas, Houston) 5'-CGACCCTAACTTTATGGCTAT and 3'-GGACAGAGCAAGACCTTTTAC (311 bp). The specificity of the PCR reactions was verified for these primers by restriction mapping of the PCR products. To distinguish between the Pax3 gene expressed in the dorsalneural tube and the expression of that gene in the dermomyotome, we performed a chick-quail chimera experiment recombining midline tissues from quail with chick somites. Consistent with the high degree of similarity between the chick and the quail genomes, we found that the chick Pax3 primers that we used amplified both chick and quail Pax3 transcripts with similar efficiency. Msp1 cut the chick Pax3 PCR prduct into 100- and 115-bp fragments whereas the quail Pax3 remained uncut.

\section{Acknowledgments}

We thank Randy Johnson for kindly supplying us with a chick $\mathrm{N}$ oggin probe prior to publication, Richard Harland and Hazel Sive for supplying us with N oggin expression vehicles, Genetics Institute for kindly supplying us with purified BM Ps, Helge Amthor, Javier Capdevila, Bodo Christ, Richard Harland, Randy Johnson, Andy M cM ahon, Ketan Patel, and Olivier Pourquié for sharing unpublished data with us, Doug Spicer and Tom Schultheiss for advise during the course of this work, and our anonymous reviewers and members of our laboratory for their insightful comments on our manuscript. This work was supported by grants to A.B.L. from the $\mathrm{N}$ ational Science Foundation and the National Institutes of Health (NIH) (GM 54879). This work was done during the tenure of an established investigatorship from the American Heart Association to A.B.L. R.R. was supported by a fellowship from the Fulbright Foundation. M.M. was supported by fellowships from the Spanish M inistry of Education and Science/Fulbright and the Human Frontier Science Program Organization.

The publication costs of this article were defrayed in part by payment of page charges. This article must therefore be hereby marked "advertisement" in accordance with 18 USC section 1734 solely to indicate this fact.

\section{References}

Amthor, H., D. Connolly, K. Patel, B. Brand-Saberi, D.G. Wilkinson, J. Cooke, and B. Christ. 1996. The expression and regulation of follistatin and a follistatin-like gene during avian somite compartmentalization and myogenesis. Dev. Biol. 178: 343-362.

Avery, G., M. Chow, and H. Holtzer. 1956. An experimental analysis of the development of the spinal column. J. Exp. Zool. 132: 409-425.

Barth, J. and R. Ivarie. 1994. Polyvinyl alcohol enhances detection of low abundance transcripts in early stage quail embryos in a nonradi oactive whole mount in situ hybridization technique. Biotechniques 17: 324-327. 
Basler, K., T. Edlund, T. Jessel, and T. Yamada. 1993. Control of cell pattern in the neural tube: Regulation of cell differentiation by dorsalin-1, a novel TGF- $\beta$ family member. Cell 73: 687-702.

Buckingham, M. 1992. Making muscle in mammals. Trends Genet. 8: 144-149.

Buffinger, N. and F.E. Stockdale. 1994. Myogenic specification in somites: Induction by axial structures. Development 120: $1443-1452$.

- - 1995. M yogenic specification of somites is mediated by diffusible factors. Dev. Biol. 169: 96-108.

Chiang, C., Y. Litingtung, E. Lee, K.E. Young, J.L. Corden, H. Westphal, and P.A. Beachy. 1996. Cyclopia and defective axial patterning in mice lacking Sonic hedgehog gene function. Nature 383: 407-413.

Christ, B. and C.P. Ordahl. 1995. Early stages of chick somite development. A nat. Embryol. 191: 381-396.

Christ, B., B. Brand-Saberi, M. Grim, and J. Wilting. 1992. Local signalling in dermomyotomal cell type specification. Anat. Embryol. 186: 505-510.

Cossu, G., R. Kelly, S. Tajbakhsh, S. Di Donna, E. Vivarelli, and M. Buckingham. 1996. Activation of different myogenic pathways: Myf5 is induced by the neural tube and MyoD by the dorsal ectoderm in mouse paraxial mesoderm. Development 122: 429-437.

Denetclaw, Jr., W.F., B. Christ, and C.P. Ordahl. 1997. Location and growth of epaxial myotome precursor cells. Development 124: 1601-1610.

Dosch, R., V. Gawantka, H. Delius, C. Blumenstock, and C. Niehrs. 1997. Bmp-4 acts as a morphogen in dorsoventral mesoderm patterning in Xenopus. Development 124: 23252334.

Fan, C.-M. and M. Tessier-Lavigne. 1994. Patterning of mammalian somites by surface ectoderm and notochord: Evidence for sclerotome induction by a hedgehog homolog. Cell 79: 1175-1186.

Gamel, A.J., B. Brand-Saberi, and B. Christ. 1995. Halves of epithelial somites and segmental plate show distinct muscle differentiation behavior in vitro compared to entire somites and segmental plate. Dev. Biol. 172: 625-639.

Goulding, M., A. Lumsden, and A.J. Paquette. 1994. Regulation of Pax-3 expression in the dermomyotome and its role in muscle devel opment. Development 120: 957-971.

Graff, J.M. 1997. Embryonic patterning: To BM P or not to BM P, that is the question. Cell 89: 171-174.

Graham, A. and A. Lumsden. 1996. Interactions between rhombomeres modulate Krox-20 and follistatin expression in the chick embryo hindbrain. Development 122: 473-480.

Hamburger, V. and H.L. Hamilton. 1951. A series of normal stages in the development of the chick embryo. J. Morphol. 88: 49-92.

Harland, R.M. 1994. The transforming growth factor $\beta$ family and induction of the vertebrate mesoderm: Bone morphogenetic proteins are ventral inducers. Proc. Natl. Acad. Sci. 91: 10243-10246.

Johnson, R.L., E. Laufer, R.D. Riddle, and C. Tabin. 1994. Ectopic expression of Sonic hedgehog alters dorsal-ventral patterning of somites. Cell 79: 1165-1173.

Kenny-M obbs, T. and P. Thorogood. 1987. Autonomy of differentiation in avian brachial somites and the influence of adjacent tissues. Development 100: 449-462.

Lamb, T.M., A.K. Knecht, W.C. Smith, S.E. Stachel, A.N. Economides, and N. Stahl, G.D. Yancopolous, and R.M. Harland. 1993. Neural induction by the secreted polypeptide noggin. Science 262: 713-718.

Laverriere, A.C., C. M acN eill, C. Mueller, R.E. Poelmann, J.B.E.
Burch, and T. Evans. 1994. GATA-4/5/6, a subfamily of three transcription factors transcribed in developing heart and gut. J. Biol. Chem. 269: 23177-23184.

Liem, K.F., G. Tremml, H. Roelink, and T.M . Jessell. 1995. Dorsal differentiation of neural plate cells induced by BM P-mediated signals from epidermal ectoderm. Cell 82: 969-979.

M arcelle, C., J. Wolf, and M. Bronner-Fraser. 1995. The in vivo expression of the FGF receptor FREK mRNA in avian myoblasts suggests a role in muscle growth and differentiation. Dev. Biol. 172: 100-114.

Maroto, M., R. Reshef, A.E. M ünsterberg, S. Koester, M. Goulding, and A.B. Lassar. 1997. Ectopic Pax-3 activates M yoD and Myf-5 expression in embryonic mesoderm and neural tissue. Cell 89: 139-148.

Matzuk, M.M., N. Lu, H. Vogel, K. Sellheyer, D.R. Roop, and A. Bradley. 1995. Multiple defects and perinatal death in mice deficient in follistatin. Nature 374: 360-363.

M ünsterberg, A.E. and A.B. Lassar. 1995. Combinatorial signals from the neural tube, floor plate and notochord induce myogenic bHLH gene expression in the somite. Development 121: $651-660$.

M ünsterberg, A.E., J. Kitajewski, D.A. Bumcrot, A.P. M cM ahon, and A.B. Lassar. 1995. Combinatorial signaling by Sonic hedgehog and Wnt family members induces myogenic bHLH gene expression in the somite. Genes \& Dev. 9: 2911-2922.

N eave, B., N. Holder, and R. Patient. 1997. A graded response to BM P-4 spatially coordinates patterning of the mesoderm and ectoderm in the zebrafish. Mech. Dev. 62: 183-195.

Ordahl, C.P. 1993. Myogenic lineages within the developing somite. In Molecular basis of morphogenesis, pp. 165-176. Wiley-Liss, N ew York, NY.

Ordahl, C.P. and N. Le Douarin. 1992. Two myogenic lineages within the developing somite. Development 114: 339-353.

Ott, M.O., E. Bober, G. Lyons, H. Arnold, and M. Buckingham. 1991. Early expression of the myogenic regulatory gene, myf5 , in precursor cells of skel etal muscle in the mouse embryo. Development 111: 1097-1107.

Pourquié, O., M. Coltey, C. Bréant, and N.M . Le Douarin. 1995. Control of somite patterning by signals from the lateral plate. Proc. Natl. Acad. Sci. 92: 3219-3223.

Pourquié, O., C.-M. Fan, M. Cotley, E. Hirsinger, Y. Watanabe, C. Bréant, P. Francis-West, P. Brickell, M. Tessier-Lavigne, and N.M. Le Douarin. 1996. Lateral and axial signals involved in avian somite patterning: A role for BMP4. Cell 84: 461-471.

Pownall, M.E. and C.P. Emerson, Jr. 1992. Sequential activation of three myogenic regulatory genes during somite morphogenesis in quail embryos. Dev. Biol. 151: 67-79.

Re'em-Kalma, Y., T. Lamb, and D. Frank. 1995. Competition between noggin and bone morphogenetic protein 4 activities may regulate dorsalization during Xenopus development. Proc. Natl. Acad. Sci. 92: 12141-12145.

Roelink, H., A. A ugsburger, J. Heemskerk, V. Korzh, S. N orlin, A. Ruiz i Altaba, Y. Tanabe, M. Placzek, T. Edlund, T.M. Jessell, and J. Dodd. 1994. Floor plate and motor neuron induction by vhh-1, a vertebrate homolog of hedgehog expressed by the notochord. Cell 76: 761-775.

Rong, P.M., M.A. Teillet, C. Ziller, and N.M . Le Douarin. 1992. The neural tube/floor plate/notochord complex is necessary for vertebral but not limb and body wall striated muscle differentiation. Development 115: 657-672.

Sasai, Y. and E.M. De Robertis. 1997. Ectodermal patterning in vertebrate embryos. Dev. Biol. 182: 5-20.

Schultheiss, T.M., S. Xydas, and A.B. Lassar. 1995. Induction of avian cardiac myogenesis by anterior endoderm. Development 121: 4203-4214. 
Schultheiss, T.M., J.B.E. Burch, and A.B. Lassar. 1997. A role for bone morphogenetic proteins in the induction of cardiac myogenesis. Genes \& Dev. 11: 451-462.

Smith, W.C., A.K. Knecht, M. Wu, and R.M. Harland. 1993. Secreted noggin protein mimics the Spemann organizer in dorsalizing Xenopus mesoderm. Nature 361: 547-549.

Spence, M.S., J. Y ip, and C.A. Erickson. 1996. The dorsal neural tube organizes the dermamyotome and induces axial myocytes in the avian embryo. Development 122: 231-241.

Stern, H.M. and S.D. Hauschka. 1995. Neural tube and notochord promote in vitro myogenesis in single somite explants. Dev. Biol. 167: 87-103.

Stern, H.M., A.M .C. Brown, and S.D. Hauschka. 1995. Myogenesis in paraxial mesoderm: Preferential induction by dorsal neural tube and by cells expressing Wnt-1. Development 121: 3675-3686.

Tajbakhsh, S., D. Rocancourt, G. Cossu, and M. Buckingham. 1997. Redefining the genetic hierarchies controlling skel etal myogenesis: Pax-3 and myf-5 act upstream of M yoD. Cell 89: 127-138.

Tonegawa, A., N. Funayama, N. U eno, and Y. Takahashi. 1997. Mesodermal subdivion along the mediolateral axis in chicken controlled by different concentrations of BMP-4. Development 124: 1975-1984.

Vivarelli, E. and G. Cossu. 1986. Neural control of early myogenic differentiation in cultures of mouse somites. Dev. Biol. 117: 319-325.

Watanabe, Y. and N.M. Le Douarin. 1996. A role for BM P-4 in the development of subcutaneous cartilage. Mech. Dev. 57: 69-78.

Wilkinson, D.G. 1993. In situ hybridization. In Essential developmental biology, a practical approach, (ed. C.D. Stern and P.W.H. Holland), pp. 257-274. IRL Press, Oxford, UK.

Williams, B.A. and C.P. Ordahl. 1994. Pax-3 expression in segmental mesoderm marks early stages in myogenic cell specification. Development 120: 785-796.

Wilson, P.A. and A. Hemmati-Brivanlou. 1997. Vertebrate neural induction: Inducers, inhibitors, and a new synthesis. Neuron 18: 699-710.

Zimmerman, L.B., J.D. Jesus-Escobar, and R.M. Harland. 1996. The Spemann organizer signal noggin binds and inactivates bone morphogenetic protein-4. Cell 86: 599-606. 


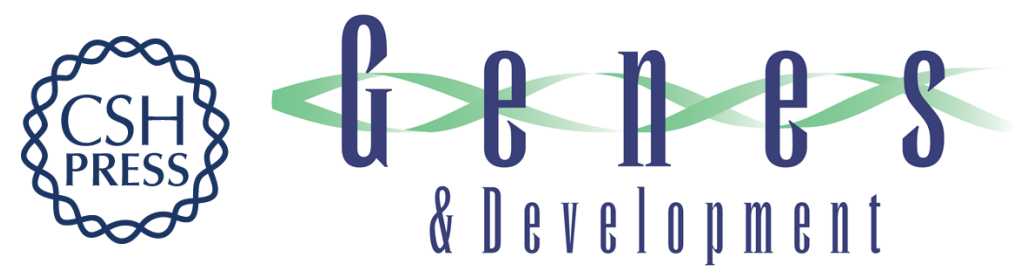

\section{Regulation of dorsal somitic cell fates: BMPs and Noggin control the timing and pattern of myogenic regulator expression}

Ram Reshef, Miguel Maroto and Andrew B. Lassar

Genes Dev. 1998, 12:

References This article cites 53 articles, 23 of which can be accessed free at: http://genesdev.cshlp.org/content/12/3/290.full.html\#ref-list-1

License

Email Alerting

Receive free email alerts when new articles cite this article - sign up in the box at the top Service right corner of the article or click here.

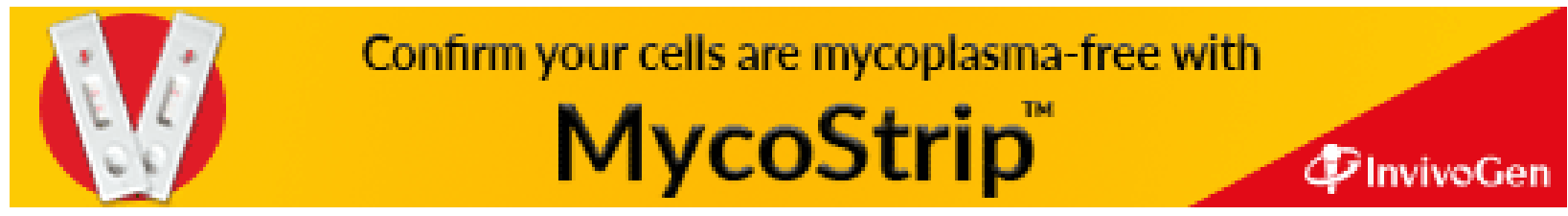

